\title{
Genetic structure of remnant black poplar (Populus nigra L.) populations along biggest rivers in Serbia assessed by SSR markers
}

\author{
Dijana Čortan ${ }^{1 *}$, Hilke Schroeder ${ }^{2}$, Mirjana Šijačić-Nikolić3 ${ }^{3}$, Christian Wehenkel ${ }^{4}$, \\ Matthias Fladung ${ }^{2}$,
}

1 Faculty of Education, University of Novi Sad, Sombor, 25000, Serbia,

2 Thünen-Institute (TI) of Forest Genetics, Grosshansdorf, D-22927, Germany

3 Faculty of Forestry, University of Belgrade, Belgrade, 11000, Serbia

4 Instituto de Silvicultura e Industria de la Madera, Universidad Juárez del Estado de Durango, C.P. 34120 Durango, México

\footnotetext{
* Corresponding author: Dijana Čortan, Phone: +381637405954,

E-mail: dijana.cortan@pef.uns.ac.rs; dijanacortan@yahoo.com
}

\begin{abstract}
Black poplar (Populus nigra L.) is a keystone species of riparian softwood forests along riversides in vast areas of Europe, Western Asia and Northern Africa. Since the end of the $20^{\text {th }}$ century, black poplar has been recognized as an endangered species throughout Europe due to the loss of its natural habitat and possible crossbreeding with hybrid poplars. Using twelve nuclear SSR loci, we analysed the genetic structure of four native populations from three river valleys in the northern part of Serbia. All tested loci were highly polymorphic, displaying 8 to 25 alleles per locus, overall 179 detected alleles and an average effective number of alleles 5.87. Observed heterozygosity (overall $\mathrm{Ho}=0.703$ ) has been lower than the expected (overall $H_{e}=0.808$ ) in each population, which indicates positive mean of fixation index values (overall $F_{i s}>0(0.132)$ ). An AMOVA analysis revealed that the highest degree of genetic variation occurred within populations $(95.33 \%)$ while the genetic variation between populations was really low (4.67\%). High gene flow and no significant loss of allelic diversity have been recorded in the studied populations in Serbia.
\end{abstract}

Keywords: Populus nigra L.; genetic differentiation; microsatellite marker; population structure; population genetics; endangered species.

\section{Introduction}

Populus nigra L. is a keystone pioneer species of riparian ecosystems, which contribute to the natural control of flooding and water quality. Riparian ecosystems are characterized by a high level of diversity of fauna and flora (Van der Schoot et al., 2000). Large areas of riparian forests are now fragmented and greatly reduced in size (Heinze, 2008) due to human impact. Reasons behind this decrease are over-exploitation, frequent and broad use of hybrid poplars which may represent a great risk for genetic introgression of foreign germplasm into native $P$. nigra populations, and hydro-melioration activities and altered natural flow regime, which caused a lack of suitable sites for natural regeneration. This has caused a severe reduction in the size of P. nigra local populations, which are no longer continuous along the river systems. Recently, many subpopulations of black poplar have been identified as unit in strong age structure, where successful natural regeneration is absent due to inappropriate conditions (Rathmacher et al., 2009).

Starting from the end of the $20^{\text {th }}$ century, P. nigra received intensive attention as an endangered species in the western part of its distribution range, hence there have been many studies on P. nigra inventory (EUFORGEN - Populus nigra network, established 1994), and introgression and gene flow examination (Cagelli and Lefèvre, 1995; Heinze, 1997; 2008; Imbert 
and Lefèvre, 2003; Fossati et al., 2003; Vanden Broeck et al., 2004; Rathmacher et al., 2009). Furthermore, morphological variability has been used for the differentiation of populations (van Dam, 2002a; Brus et al., 2010; Čortan et al., 2013; 2014; 2015). However, considerable attention has been paid to the evaluation of the existing genetic diversity of P. nigra in many parts of Europe (Legionnet et al., 1996; Arens et al., 1998; van Dam, 2002a; Cottrell et al., 1997; 2005; Pospiskova and Bartakova, 2004; Storme et al., 2004; Smulders et al., 2008; Maksimović et al., 2014; Jelić et al., 2015) as an indicator of the endangerment of this river landscape's shaping species.

It has been estimated that $99 \%$ of the riparian forests in Europe disappeared since the beginning of the $20^{\text {th }}$ century (Lefèvre et al., 1998; Smulders et al., 2008) as a result of human activities. In Serbia, where $P$. nigra occurs in the native riparian forests of Vojvodina, this decrease has been observed as well. With less than $7.1 \%$ of its total area, currently, the area of Vojvodina is one of the regions with the lowest forest coverage in Europe (Banković et al., 2009). In the total forest area native poplars account for only $1.9 \%$ and of these, P. nigra represents only $15.9 \%$, while Populus hybrids account for $20.5 \%$ (Radosavljević, 2009). Although, natural populations of $P$. nigra in the northern part of Serbia are still partially widespread, natural regeneration is very infrequent and remaining solitary old trees prevail. Several recent studies have covered $P$. nigra populations along European catchments (Smulders et al., 2001, 2008a; Imbert and Lefèvre, 2003; Rathmacher et al., 2009; Jelić et al., 2015), however, there is no information available on genetic diversity and gene flow for Serbian black poplar populations. In addition, no conservation strategies have been initiated so far.

This area of the Balkan Peninsula is considered the northern border of one important glacial refugium for many plant and animal species in Europe (Jelić et al., 2015). Several studies confirmed that forest tree species, including $P$. nigra, were distributed during glacial in the Balkans and spread northward from the refugial area afterwards (Hewitt, 2000; Bordács et al., 2002; Cottrell et al., 2005; Jelić et al., 2015). Since the refugial areas tend to have great genetic diversity (Leroy and Arpe, 2007), they should be the focus of further conservation strategy measures (Jelić et al., 2015). Hence, the knowledge of genetic diversity and population structure in Serbia's remaining populations, as a part of northern Balkans refugium, is an important prerequisite for the successful conservation management strategies of this region's riparian forests.

The availability of highly polymorphic microsatellite markers spurred a recent wave of population genetic studies in the Populus species (Storme et al., 2002; 2004; Smulders et al., 2001; 2008; van Dam, 2002a; van Dam et al., 2002b; Alba et al., 2002; Gebhardt et al., 2002; Grassi et al., 2002; Fossati et al., 2003; Pospiskova and Bartakova, 2004; Wang et al., 2011; Jelić et al., 2015). Those studies have demonstrated a high level of genotypic diversity within and between poplar populations based on microsatellite markers. Furthermore, microsatellite markers have also been useful for the identification of poplar clones (Schroeder and Fladung, 2010; Orlović et al., 2009) and to examine their transferability to different poplar sections
(Bruegmann and Fladung, 2013). According to these previous studies, the microsatellite marker analysis appeared to be the most appropriate for calculating gene diversity and tracing identical genotypes.

In this study, we examined the genetic structure of four native $P$. nigra populations of the three biggest river valleys in the region of Vojvodina, Serbia, using 12 microsatellite markers. The aims were (i) obtaining a better understanding of the complex interactions between local dispersion, ecological behaviour, and present diversity of the species and (ii) fill a gap on the European black poplar genetic map. As dioecious species, $P$. nigra is supposed to have more efficient dispersal mechanisms for pollen (wind) and seeds (wind and water) than other tree species, we expected to find a high level of genetic diversity and low differentiation among populations (Imbert and Lefèvre, 2003).

\section{Materials and Methods}

\section{Study area}

In order to determine the genetic structure of $P$. nigra, we studied four native black poplar populations in the region of Vojvodina (northern part of Serbia). These four populations inhabit the basins of Danube, Sava and Tisa Rivers. The selected sites have uniform characteristics, flat ground, with-out significant exposure, situated next to the bank of the rivers as a part of the tree species community of willow and black poplar. Exact positions of studied sites are given in Table 1 and Figure 1.

\section{Table 1}

Studied populations of native black poplar in a northern part of Serbia (the UTM Gauss-Krueger-based coordinate systems has been used).

\begin{tabular}{llrcc} 
Population & $\begin{array}{l}\text { Location - } \\
\text { River basin }\end{array}$ & \multicolumn{2}{c}{ Coordinates } & Altitude range (m) \\
& & $\mathrm{x}$ & $\mathrm{y}$ & \\
\hline A & Upper Danube & 7338178 & 5064085 & $82-87$ \\
B & Tisa & 7446577 & 5008043 & $72-80$ \\
C & Sava & 7413348 & 4951019 & $76-78$ \\
D & Lower Danube & 7510888 & 4955118 & $66-82$ \\
\hline
\end{tabular}

\section{Plant material}

Leaves from thirty adult trees from each of the four sites were used for the analyses (in total 120 individuals). Each individual was randomly selected and separated at least $100 \mathrm{~m}$ from the next one. The distance of about $100 \mathrm{~m}$ between investigated individuals was chosen to avoid clonal structure because of root suckers to the largest possible extent (Wei et al., 2013). The leaf samples were collected in October 2013, subsequently dried and preserved in plastic grip seal bags with silica gel prior to DNA isolation. 


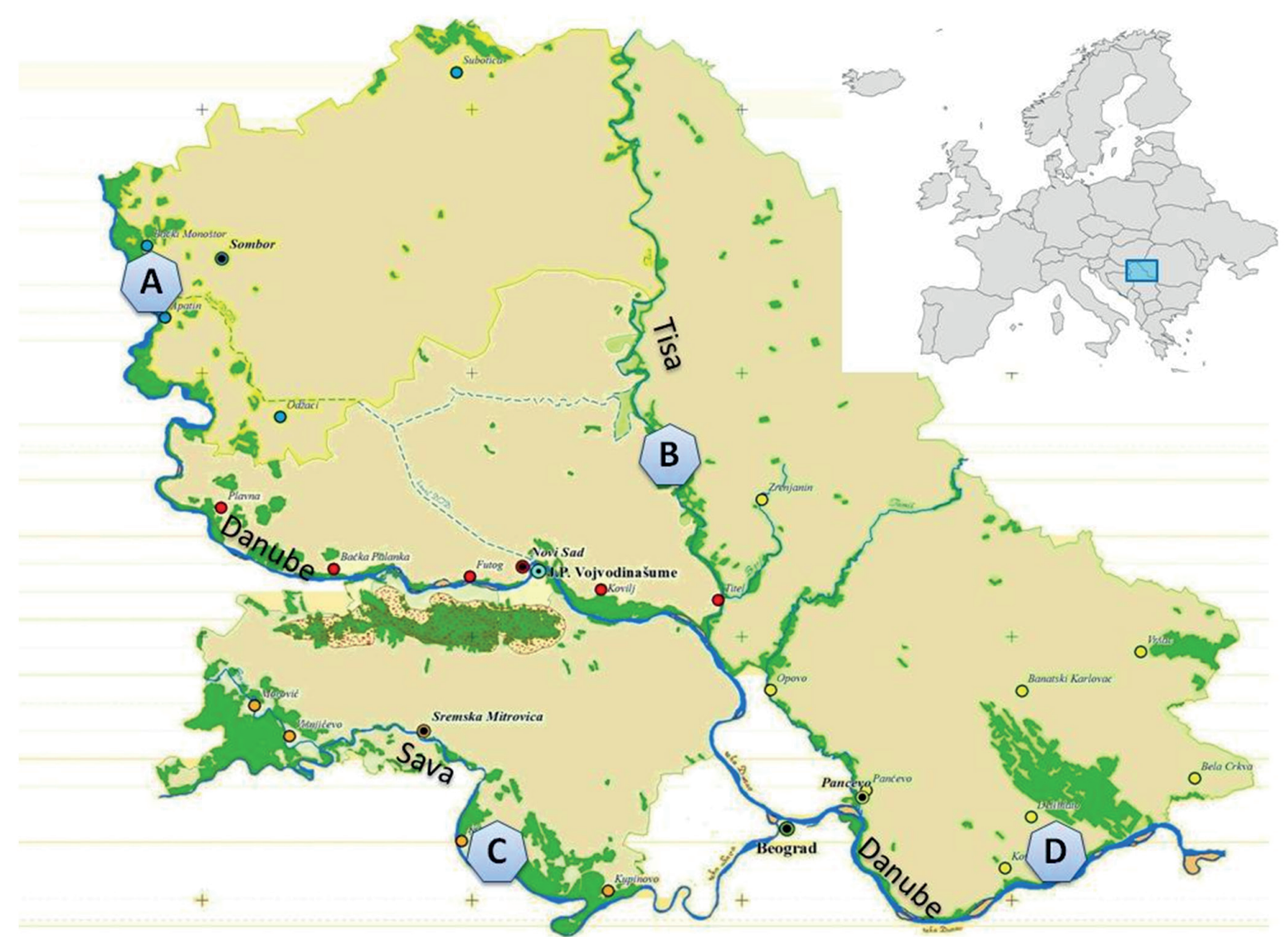

Figure 1

Forest coverage map of Vojvodina region, northern Serbia, with selected sites: A - upper Danube, B - Tisa, C - Sava and D - lower Danube population (modified Čortan et al., 2015).

\section{DNA extraction}

DNA was extracted according to the protocol of Dumolin et al. (1995). The polymerase chain reaction (PCR) was performed according to Pakull et al. (2009), in a total volume of $25 \mu \mathrm{l}$ containing $80 \mathrm{ng}$ of template DNA. Annealing temperatures were in the range of 50 to $65^{\circ}$, depending on used primers (Supplementary file 1). The PCR-amplified products were electrophorised on a $1 \%$ agarose gel and visualized by Roti-Safe Gelstain (Carl Roth, Karlsruhe, Germany), to check for successful fragment amplification.

\section{Marker analysis}

In total, 12 microsatellite (SSR) loci were used (PMGC14, PMGC2020, PMGC2163, PMGC2550, PMGC2607, PMGC2679, WPMS09, WPMS14, WPMS16, WPMS17, WPMS18, WPMS20). Those with PMGC prefix were selected from International Populus Genome Consortium IPGR SSR resource (http://www. ornl.gov/sci/ipgc/ssr resource.htm), others with WPMS prefix were developed by the Center for Plant Breeding and Reproduction Research (van der Schoot et al., 2000; Smulders et al., 2001).

The PCR products were separated using the automatic sequencing unit ALFexpress II (GE Healthcare) under the following conditions: running time 105 to $180 \mathrm{~min}$, short gel plate with $6 \%$ polyacrylamide gel ( $14.7 \mathrm{~g}$ UREA, $5.25 \mathrm{ml}$ Acrylamid 40 (Carl Roth, Karlsruhe, Germany), $14.875 \mathrm{ml} \mathrm{H}_{2} \mathrm{O}, 3.6 \mathrm{ml}$ 10xTBE, $17.5 \mu$ ITEMED, $175 \mu \mathrm{I}$ APS), running temperature $55^{\circ} \mathrm{C}$ and voltage $1,500 \mathrm{~V}$. Samples were prepared according to Pakull et al. (2009), i.e., $7 \mu$ l of the PCR products were diluted in $3 \mu \mathrm{l}$ pink loading buffer, $2 \mu \mathrm{l} 1 \times \mathrm{TE}$ and $1 \mu \mathrm{l}$ of internal standard fragment solution, denaturated at $92^{\circ} \mathrm{C}$ for 3 min and cooled on ice before loading onto the gel. The band size was monitored using a $50 \mathrm{bp}$ DNA ladder ranging from 100 to $550 \mathrm{bp}$ as a reference. Internal and external band sizers are consisting out of specific fragments amplified from a bacterial vector (PGREEN). Data analysis was carried out using the Fragment Analyser software (version 1.03.01, GE Healthcare).

\section{Population genetics analysis}

The following genetic diversity parameters were determined for each locus and population: number of alleles $\left(N_{a}\right)$ and mean effective number of alleles $\left(N_{e}\right)$, allelic richness $(A r)$, number of private alleles $\left(N_{p}\right)$, observed $\left(H_{o}\right)$ and expected $\left(H_{e}\right)$ heterozygosity (Nei 1973) and F-statistics $\left(F_{i s^{\prime}} F_{s t^{\prime}} F_{i t}\right)$ (Weir and Cockerham, 1984). Genetic distance between studied sites was examined by pairwise $F_{s t}$ values. Considering that the frequently 
used fixation index, $F_{\text {st }}$ and its derivatives, when used as descriptors of genetic differentiation, may underestimate genetic differentiation and lead to erroneous conclusions, particularly when applied to highly polymorphic genetic markers (Gregorius et al., 2007), such SSRs in our case, the genetic distance between studied populations was also examined by Gregorius $d_{0}$ (1974) using GDA_NT software (Degen, 2008). For estimation of variance component and to partition the variation within and between populations, we used the analysis of molecular variance (AMOVA) for all loci. Genetic diversity parameters and a test for bottleneck (Garza-Williamson Index) have been performed using the software Arlequin version 3.5.1.2 (Excoffier and Lischer, 2010). A Principal Coordinates Analysis ( $P C O A)$ was carried out to generate a two-dimensional representation of genetic relationship between individuals of studied populations with the help of GenAlEx version 6.501 software (Peakall and Smouse, 2005). A Mantel test was employed to search for the correlation between geographic and genetic $\left(F_{s t}\right)$ distances (Nei, 1978) to detect isolation by distance. For this purpose the online tool IBDWS Version 3.23 of Jensen et al. (2005) was used.

\section{Results}

The analysis of twelve SSR markers revealed no identical genotypes within the 120 involved P. nigra specimens, thus, no clonal structure was determined.

All twelve analysed SSR loci were highly polymorphic with the least variable WPMS_16 locus and the most variable WPMS_9 locus displaying 8 and 25 alleles, respectively. No indication of null alleles was obtained. Population $A$ had the lowest number of alleles (104) while population D had the highest (137) of overall 179 detected alleles in the studied area (Table 2). The average $H_{o}$ per population ranged from 0.683 (population A) to 0.719 (population B), and the average $H_{e}$ per population ranged from 0.783 (population $A$ ) to 0.835 (population B). The average number of alleles per locus $\left(N_{a}\right)$ were at lowest 8.667 (population A) and were at highest up to 11.417 (population $D$ ), while the average effective number of alleles per locus $\left(N_{e}\right)$ ranged from 5.480 (population A) to 6.207 (population $B$ ). In total, 40 private alleles were found in the four study sites. In population A, only two private alleles were found, while the other three populations revealed ten or more private

Table 2

Mean values of main genetic characteristics of four black poplar native populations in northern Serbia.

$\begin{array}{lccccccccccccc}\begin{array}{l}\text { Study } \\ \text { sites }\end{array} & N & N_{o} & N_{a} & N_{e} & N_{p} & A_{r} & H_{o} & H_{e} & \text { G-W } & F_{i s} & p-\text { value } \\ \text { A } & 30 & 104 & 8.667 & 5.480 & 2 & 8.447 & 0.683 & 0.783 & 0.706 & 0.123 & 0.000 \\ \text { B } & 30 & 131 & 10.917 & 6.207 & 12 & 10.492 & 0.719 & 0.835 & 0.785 & 0.137 & 0.000 \\ \text { C } & 30 & 122 & 10.167 & 5.752 & 10 & 9.726 & 0.701 & 0.800 & 0.747 & 0.125 & 0.000 \\ \text { D } & 30 & 137 & 11.417 & 6.051 & 16 & 10.822 & 0.708 & 0.812 & 0.687 & 0.125 & 0.000 \\ \text { overall } & 120 & 179 & 10.292 & 5.872 & 40 & 9.872 & 0.703 & 0.808 & 0.731 & 0.132 & 0.000\end{array}$

$N$-number of individuals; $N_{o}$ - overall number of alleles per population, $N_{a}$ - mean number of alleles per locus; $N_{e}-$ effective number of alleles; $N_{p}-$ number of private alleles; $A_{r}-$ Allelic

Richness; $H_{o}$ - observed heterozygosity; $H_{e}$ - expected heterozygosity; $G-W$ - Garza-Williamson index; $F_{i s}$ - inbreeding coefficient among individuals within subpopulations and it's p-values.

Table 3

Characteristics of microsatellite markers used in black poplar variability analysis.

\begin{tabular}{|c|c|c|c|c|c|c|c|}
\hline locus & $N_{o}$ & $A_{r}$ & $H_{0}$ & $H_{e}$ & $F_{i s}$ & $F_{s t}$ & $F_{i t}$ \\
\hline PMGC_14 & 12 & 8.246 & 0.767 & 0.825 & 0.072 & 0.025 & 0.095 \\
\hline PMGC_2020 & 19 & 9.916 & 0.642 & 0.777 & 0.177 & 0.056 & 0.223 \\
\hline PMGC_2163 & 20 & 15.258 & 0.775 & 0.923 & 0.163 & 0.005 & 0.167 \\
\hline PMGC_2550 & 15 & 8.015 & 0.558 & 0.732 & 0.241 & 0.14 & 0.347 \\
\hline PMGC_2607 & 22 & 14.029 & 0.683 & 0.881 & 0.227 & 0.017 & 0.240 \\
\hline PMGC_2679 & 10 & 7.200 & 0.650 & 0.777 & 0.166 & 0.056 & 0.212 \\
\hline WPMS_9 & 23 & 14.597 & 0.704 & 0.904 & 0.229 & 0.03 & 0.252 \\
\hline WPMS_14 & 18 & 11.521 & 0.725 & 0.830 & 0.128 & 0.017 & 0.143 \\
\hline WPMS_16 & 8 & 5.826 & 0.667 & 0.738 & 0.099 & 0.082 & 0.173 \\
\hline WPMS_17 & 9 & 5.439 & 0.642 & 0.629 & -0.021 & 0.067 & 0.047 \\
\hline WPMS_18 & 12 & 8.055 & 0.808 & 0.811 & 0.004 & 0.014 & 0.018 \\
\hline WPMS_20 & 11 & 10.359 & 0.817 & 0.865 & 0.057 & 0.024 & 0.080 \\
\hline overall & 179 & 9.872 & 0.703 & 0.808 & 0.132 & 0.043 & 0.170 \\
\hline
\end{tabular}


alleles. The highest number of private alleles (7) was observed for the locus WPMS_20 (Table 2). The Garza-Williamson index was very small in populations that have been gone through a bottleneck. The analysis of bottleneck resulted in no such effect for all four populations shown by the overall mean values of $G-W$ index for all populations that were between 0.687 and 0.785 (Table 2).

The analysis of the characteristics of all twelve loci revealed a positive mean of fixation index values across all studied sites $\left(F_{i s}=0.132\right.$, Table 3$)$. The values for single loci ranged from -0.021 (WPMS_17) to 0.241 (PMGC_2550), and the estimation of $F_{\text {st }}(0.043)$ showed a low level of differentiation over all studied populations (Table 3). Overall F indices showed statistically significant values $(p<0.0001)$. The AMOVA analyses across all loci indicated that $4.67 \%$ of genetic variance occurred among populations, while the much greater amount of genetic variance $(95.33 \%)$ counted as differences within populations (Table 4).

\section{Table 4}

AMOVA for all loci: partitioning of genetic variation among black poplar populations, among individuals and within populations of Serbia.

\begin{tabular}{lcccc}
$\begin{array}{l}\text { Source of } \\
\text { variation }\end{array}$ & $\begin{array}{r}\text { Sum of } \\
\text { squares }\end{array}$ & $\begin{array}{c}\text { Variance } \\
\text { components }\end{array}$ & $\begin{array}{c}\text { Percentage of } \\
\text { variation } \%\end{array}$ & $p$-value \\
$\begin{array}{l}\text { Among } \\
\text { populations }\end{array}$ & 51.892 & 0.215 & 4.67 & 0.0000 \\
$\begin{array}{l}\text { Within } \\
\text { populations }\end{array}$ & 1037.083 & 4.394 & 95.33 & 0.0000 \\
$\begin{array}{l}\text { Total } \\
\text { 1088.975 }\end{array}$ & 4.609 & & \\
\hline
\end{tabular}

Pairwise $F_{\text {st }}$ values were low, while genetic differentiation calculated by $d_{0}$ was moderate and much higher than $\mathrm{F}_{\text {st. }}$. Both pairwise values, $F_{s t}$ and $d_{o^{\prime}}$, were statistically significant $(p<0.0001$, result not shown). However, both parameters showed that the most distinct ones are populations $A$ and $C$ (Table 5), while population $B$ is the closest to other studied populations.

Table 5

Genetic distances $\mathrm{F}_{\mathrm{st}} / d_{0}$ (below diagonale) and geographical distances (above diagonal - $\mathrm{km}$ ) between studied sites. (All pairwise genetic distances values were statistically significant for $p<0.0001)$

$\begin{array}{cccccc} & \text { A } & \text { B } & \text { C } & \text { D } \\ \text { A } & - & 122.02 & 135.67 & 204.20 \\ \text { B } & 0.028 / 0.236 & - & 66.00 & 83.28 \\ \text { C } & 0.045 / 0.397 & 0.024 / 0.224 & - & 97.62 \\ \text { D } & 0.039 / 0.333 & 0.020 / 0.118 & 0.036 / 0.345 & -\end{array}$

The Mantel test resulted in a correlation coefficient between genetic and geographic distances of $r=0.559$, indicating that there is no isolation by distance between the studied populations $(p=0.254)$.

\section{Discussion}

In the present study, information on the current genetic structure in four native $P$. nigra L. populations in the three biggest river valleys in the northern part of Serbia was obtained. A high level of polymorphism was detected in all four populations given the numbers of alleles per population (Table 2) and per locus (Table 3) and confirms our hypothesis on existence of high level of genetic diversity. The observed heterozygosity (overall $H_{o}=0.703$ ) was slightly lower than the expected one (overall $H_{e}=0.808$ ). Similar levels of heterozygosity were reported for $P$. nigra populations along the Rhine river $\left(H_{o}=0.68\right.$, $H_{e}=0.73$; van Dam et al., 2002b), the Morava river $\left(H_{o}=0.793\right.$, $H_{e}=0.829$; Pospiskova and Bartakova, 2004), the Eder river $\left(H_{o}=0.70, H_{e}=0.73\right.$; Rathmacher et al., 2009) as well as Danube river $\left(H_{o}=0.695, H_{e}=0.811\right.$; Jelić et al., 2015). For several other poplar species, however, lower levels of polymorphism have been reported: $P$. tremuloides $\left(H_{o}=0.47, H_{e}=0.67\right.$; Namroud et al., 2005), P. alba $\left(H_{o}=0.341, H_{e}=0.368\right.$; Lexer et al., 2005), P. tremula $\left(H_{o}=0.466, H_{e}=0.512\right.$; Lexer et al., 2005) and P. tomentosa $\left(H_{o}=0.572, H_{e}=0.446\right.$; Du et al., 2012). Even though the same loci have not been used in all these studies, as was in the Serbian populations, in all these populations it have been recorded that $H_{e}$ was higher than $H_{o}$ implying a greater excess of homozygotes which is most often a result of inbreeding. However, according to Pospiskova and Salkova (2006), positive $F_{\text {is }}$ values only suggest inbreeding when all studied loci show equally high values. This is not the case for Serbian populations (Table 3). Thus, the significantly positive value for overall $F_{\text {is }}$ only points to weak inbreeding tendency.

The overall degree of population differentiation was low $\left(F_{s t}=0.043, p<0.0001\right)$, but still significantly higher than zero. Considering the above pointed out weaknesses of $F_{s t}$ index (Gregorius et al., 2007), genetic differentiation $\left(d_{0}\right)$ was also calculated (Gregorius, 1974), showing much higher distances than $\mathrm{F}_{s t^{\prime}}$ which indicated moderate differentiation among present populations. Still statistically significant differences exist between all pairs of studied populations, but genetic distance is not correlated with geographic distance according to the Mantel test $(p=0.254)$. The low pairwise $F_{s t}$ values and the results of partitioning of genetic variation (AMOVA) indicate that the four populations in Serbia are highly similar in their genetic compositions as observed in other P. nigra populations conducted in small areas (Gebhardt et al., 2002; van Dam et al., 2002b; Pospiskova and Bartakova, 2004; Imbert and Lefèvre, 2003).

Such outcome was certainly expected, considering that the examined research area is only $21,506 \mathrm{~km}^{2}$, with populations distances of 66 to $204 \mathrm{~km}$, where gene flow is possible by wind (pollen and seed) and secondly by river flow (seed) as has been shown by Van Splunder et al. (1995). Thus, pollen and seeds can be dispersed over large distances and therefore even populations from different river catchments could be genetically very similar if geographical barriers hindering gene flow 
are missing (Jelić et al., 2015). Nevertheless, there are differences in the genetic distances between populations presented here. The genetically most distinct populations are A and C, both located in different river valleys but with the same flow direction towards population D. These populations are $135 \mathrm{~km}$ apart from each other and they are separated by the Fruška Gora hill with an altitude of $539 \mathrm{~m}$. Thus, this might influence gene flow among these two populations. There is a high potential in pollen-mediated gene flow, for example for oak pollen a transport of up to $100 \mathrm{~km}$ is reported (Schueler et al., 2005). However, the geographical distance, the physiographic barrier and few poplar stands as stepping stones between these two populations, $A$ and $C$, makes it very difficult to have a high pollen transport. Populations $B$ and $D$ are close to each other in a genetic sense as well as geographically $(83 \mathrm{~km})$ and by the river flow (about $122.5 \mathrm{~km}$ ) and since there are no topographical obstacles, the gene flow between them is highly probable, reflected in the lower genetic distance value. In contrast, populations $C$ and $D$ are also geographically close to each other $(98 \mathrm{~km}$ ) and also by river flow (about $220 \mathrm{~km}$ ), but genetically clearly more different than the populations $B$ and $D$. The geographically most distant populations are the A and D (204 km), separated about $350 \mathrm{~km}$ by the river flow, and they are also genetically very different, whereas populations $B$ and $C$ from different river valleys are geographically least distant to each other $(66 \mathrm{~km})$ but not from a genetic point of view. Since all flow directions lead to population $D$, a part of seed dispersal should be directed from North-West to South-East towards population $D$ following the rivers. However the prevailing wind (named Košava) comes from South-East, indicating main pollen dispersal opposite to the river flow direction. Since pollen dispersal is generally considered to be more effective for long-distance gene flow than seed dispersal (Imbert and Lefèvre, 2003; Rathmacher et al., 2009), we can assume that the main gene flow has SE-NW direction, same as the prevailing wind.

The great diversity of Serbian $P$. nigra populations may confirm the premise of possible $P$. nigra refugia existence in the Balkans (Cottrell et al., 2005), since it has been an important glacial refugium for many plant and animal species (Hewitt, 2000; Petit et al., 2002a; 2002b; 2003; Cottrell et al., 2005). The diversity of studied populations decreases in direction from population $D$ up to population $A$. This direction has been already suggested by Cottrell et al. (2005) as the post-glacial route of recolonization from the Balkan refugium. Assuming that the gene flow was not the main factor, the overall higher genetic diversity in populations $D$ and $B$ supports the suggestion that at least these southern populations may have been a part of glacial refugia, because it is known that tree refugia are characterised by high genetic variation (Petit et al., 2002a). The obtained results of high genetic diversity highlight the need to perform more detailed research on the exact location of the $P$. nigra refugium on the Balkan Peninsula.

\section{Conclusions}

In the four studied P. nigra populations from Serbia located along the largest rivers in the Vojvodina region, we observed a genetic variation which is consistent with other European populations along big rivers that have been characterised as having a high level of genetic diversity and low population differentiation. This genetic pattern could happen due to gene flow between the populations, which is undoubtedly likely to enhance intraspecific diversity and reduce inter-population differentiation (Hedrick, 2004).

Refugia areas represent climatically stable areas and constitute a high conservation priority as key areas for the longterm persistence of species and genetic diversity, especially given the threat posed by the extensive environmental change processes (Médail and Diadema, 2009). Therefore, present populations of still high genetic diversity which are situated in the north Balkans refugia should be considered as source populations for future conservation and restoration projects. Nevertheless, despite its importance for the long-term viability and the evolutionary potential of tree species and functioning of ecosystems, the genetic diversity of populations seldom receives explicit consideration in conservation programs (Kahilainen et al., 2014; Wehenkel et al., 2016).

\section{Acknowledgements}

The first author (DC) would like to thank the COST Action FP0905: "Biosafety of forest transgenic trees: improving the scientific basis for safe tree development and implementation of EU policy directives" for accepting and financing this Short Term Scientific Mission (STSM). DC also appreciates the Thünen Institute of Forest Genetics (Grosshansdorf, Germany) for hosting this STSM application. For generous support and skilful laboratory assistance, many thanks to the technical assistant Katrin Groppe and all her colleagues. Thanks also to Dr. Georg von Wuehlisch (Thünen Institute of Forest Genetics, Germany) for helpful comments to the manuscript, Jelena Mladjenović (English Professor) for manuscript language revision and Dr. Zoran Tomović (PE Vojvodinašume, Serbia) for field organisation.

\section{References}

Alba N, Maestro C, Agundez D, Notivol E (2002) Advances in the preservation of genetic resources in Populus nigra in Spain. In: Van Dam BC and Bordács $S$ (eds) Genetic diversity in river population of European black poplar implications for riparian eco-system management; proceedings of the International Symposium, Szekszard, Hungary:125-136

Arens P, Coops H, Jansen J, Vosman B (1998) Molecular genetic analysis of black poplar (Populus nigra L.) along Dutch rivers. Mol Ecol 7:11-18 http://dx.doi.org/10.1046/j.1365-294x.1998.00316.x 
Banković S, Medarević M, Pantić D, Petrović N, Šljukić B, Obradović S (2009) The growing stock of the Republic of Serbia-state and problems. Bull Faculty Forestry - University of Belgrade 100:7-30 http://dx.doi.org/10.2298/gsf0900007b

Bordács S, Popescu F, Slade D, CsaikI UM, Lesur I, Borovics A, Kezdy P, König AO, Gömöry D, Brewer S, Burg K, Petit RJ (2002) Chloroplast DNA variations of white oaks in northern Balkans and in the Carpathian Basin. Forest Ecol Manag 156:197-209 http://dx.doi.org/10.1016/s0378-1127(01)00643-0

Bruegmann T, Fladung M (2013) Potentials and limitations of the cross-species transfer of nuclear microsatellite marker in six species belonging to three sections of the genus Populus L. Tree Gen Genom 9:1413-1421 http://dx.doi.org/10.1007/s11295-013-0647-3

Brus R, Galien U, Božić G, Jarni K (2010) Morphological study of the leaves of two European black poplar (Populus nigra L.) population in Slovenia. Period Biol 112:317-325

Cagelli L, Lefèvre F (1995) The conservation of Populus nigra L. and gene flow with cultivated poplars in Europe. Forest Genet 2:135-144

Čortan D, Šijačić-Nikolić M, Knežević R (2013) Variability of leaves morphological traits in black poplar (Populus nigra L.) from two populations in Vojvodina. Šumarstvo 65:193-202

Čortan D, Šijačić-Nikolić M, Knežević R (2014) Variability of black poplar morphometric leaf characteristics from the area of Vojvodina. Bull Faculty Forestry University of Belgrade 109:63-72 http://dx.doi.org/10.2298/gsf1409063C

Čortan D, Tubić B, Šijačić-Nikolić M, Borota D (2015) Variability of black poplar (Populus nigra L.) leaf morphology in Vojvodina, Serbia. Šumarski list 5-6:245-252

Cottrell LE, Forrest GI, White IMS (1997) The use of RAPD analysis to study diversity in British black poplar (Populus nigra L. subsp. betulifolia (Pursh) W. Wettst., Salicaceae) in Great Britain. Watsonia 21:305-312

Cottrell JE, Krystufek V, Tabbener HE, Milner AD, Connolly T, Sing L (2005) Postglacial migration of Populus nigra L.: lessons learnt from chloroplast DNA. Forest Ecol Manag 219:293-312 http://dx.doi.org/10.1016/j.foreco.2005.10.003

Degen B (2008) GDA_NT 2.0: Genetic data analysis and numerical tests. [last change 17.11.2015]. Available from bernd.degen@thuenen.de

Du Q, Wang B, Wei Z, Zhang D, Li B (2012) Genetic diversity and population structure of Chinese white poplar (Populus tomentosa) revealed by SSR markers. J Hered 103:853-862 http://dx.doi.org/10.1093/jhered/ess061

Dumolin S, Demesure B, Petit RJ (1995) Inheritance of chloroplast and mitochondrial genomes in pedunculate oak investigated with an efficient PCR method. Theor Appl Genet 91:253-1256 http://dx.doi.org/10.1007/bf00220937

Excoffier L, Lischer HEL (2010) Arlequin suite ver 3.5: A new series of programs to perform population genetics analyses under Linux and Windows. Mol Ecol Resour 10:564-567 http://dx.doi.org/10.1111/j.1755-0998.2010.02847.x

Fossati T, Grassi F, Sala F, Castiglione S (2003) Molecular analysis of natural populations of Populus nigra L. intermingled with cultivated hybrids. Mol Ecol 12:2033-2043 http://dx.doi.org/10.1046/j.1365-294x.2003.01885.x

Gebhardt K, Pohl A, Vornam B (2002) Genetic inventory of black poplar populations in the Upper Rhine floodplains: conclusions for conservation of an endangered plant species. In: Van Dam BC and Bordács S (eds) Genetic diversity in river population of European black poplar implications for riparian eco-system management; proceedings of the International Symposium, Szekszard, Hungary:145-156

Grassi F, Winfield M, Fossati T, Sala F, Castiglione S (2002) Molecular analysis of natural populations of Populus nigra L. growing along the river Ticino in northern Italy. In: Van Dam BC and Bordács S (eds) Genetic diversity in river population of European black poplar implications for riparian eco-system management; proceedings of the International Symposium, Szekszard, Hungary:107-116

Gregorius HR (1974) Genetischer Abstand zwischen Populationen. 1. Zur Konzeption der genetischen Abstandsmessung. Silvae Genet 23:22-27
Gregorius HR, Degen B and König A (2007) Problems in the analysis of genetic differentiation among populations - a case study in Quercus robur. Silvae Genet 56:190-199

Hedrick PW (2004) Recent developments in conservation genetics. Forest Ecol Manag 197:3-19 http://dx.doi.org/10.1016/j.foreco.2004.05.002

Heinze B (1997) A PCR marker for a Populus deltoides allele and its use in studying introgression with native European Populus nigra. Belg J Bot 129:123-130

Heinze B (2008) Genetic trace of cultivated hybrid poplars in the offspring of native Populus nigra in Austria. Preslia 80:365-374

Hewitt G (2000) The genetic legacy of the quaternary ice age. Nature 405:907913 http://dx.doi.org/10.1038/35016000

Imbert E, Lefèvre F (2003) Dispersal and gene flow of Populus nigra (Salicaceae) along a dynamic river system. J Ecol 91:447-456 http://dx.doi.org/10.1046/j.1365-2745.2003.00772.x

Jelić M, Patenković A, Skorić M, Mišić D, Kurbalija Novičić Z, Bordács S, Varhidi F, Vasić I, Benke A, Frank G, Šiler B (2015) Indigenous forest of European black poplar along the Danube River: genetic structure and reliable detection of introgression. Tree Genet Genomes 11:89 http://dx.doi.org/10.1007/s11295-015-0915-5

Jensen JL, Bohonak AJ, Kelley ST (2005) Isolation by distance, web service. BMC Genetics 6:13. v.3.23 (http://ibdws.sdsu.edu/)

Kahilainen A, Puurtinen M, Kotiaho JS (2014) Conservation implications of species - genetic diversity correlations. Glob Ecol Conserv 2:315-323 http://dx.doi.org/10.1016/i.gecco.2014.10.013

Lefèvre F, Légionnet A, De Vries S, Turok J (1998) Strategies for the conservation of a pioneer tree species, Populus nigra L., in Europe. Genet Select Evol 30:181-196 http://dx.doi.org/10.1051/gse:19980711

Legionnet A, Lefèvre $F$ (1996) Genetic variation of the riparian pioneer tree species Populus nigra L. I. Study of population structure based on isoenzymes. Heredity 77:629-637 http://dx.doi.org/10.1038/hdy.1996.190

Leroy SAG, Arpe K (2007) Glacial refugia for summer-green trees in Europe and sourh-west Asia as proposed by ECHAM3 time-slice athmospheric model simulation. J Biogeogr 34:2115-2128 http://dx.doi.org/10.1111/j.1365-2699.2007.01754.x

Lexer C, Fay MF, Joseph A, Nica MS, Heinze B (2005) Barrier to gene fow between two ecologically divergent Populus species, P. alba (white poplar) and $P$. tremula (European aspen) the role of ecology and life history in gene introgression. Mol Ecol 14:1045-1057 http://dx.doi.org/10.1111/j.1365-294x.2005.02469.x

Maksimović Z, Čortan D, Ivetić V, Mladenović Drinić S, Šijačić-Nikolić M (2014) Genetic structure of black poplar (Populus nigra L.) in the area of Great war Island. J Biogeogr 46:963-973 http://dx.doi.org/10.2298/gensr1403963m

Médail F, Diadema K (2009) Glacial refugia influence plant diversity patterns in the Mediterranean Basin. J Biogeogr 36:1333-1345 http://dx.doi.org/10.1111/j.1365-2699.2008.02051.x

Namroud MC, Park A, Tremblay F, Bergeron Y (2005) Clonal and spatial genetic structures of aspen (Populus tremuloides Michx). Mol Ecol 14:2969-2980 http://dx.doi.org/10.1111/j.1365-294x.2005.02653.x

Nei M (1973) Analysis of gene diversity in subdivided populations. Proceedings of the National Academy of Sciences of the USA 70:3321-3323 http://dx.doi.org/10.1073/pnas.70.12.3321

Nei M (1978) Estimation of average heterozygosity and genetic distance from a small number of individuals. Genetics 89:583-590

Orlović S, Galović V, Zorić M, Kovačević B, Pilipović A, Galić Z (2009) Evaluation of interspecific DNA variability in poplars using AFLP and SSR markers. AFR J Biotechnol 8:5241-5247

Pakull B, Groppe K, Meyer M, Markussen T, Fladung M (2009) Genetic linkage mapping in aspen (Populus tremula L. and Populus tremuloides Michx.). Tree Genet Genom 5:505-515 http://dx.doi.org/10.1007/s11295-009-0204-2 
Peakall R, Smouse P (2005) GenAlex Version 6. Population genetics software for teaching and research. The Australian National University, Canberra, Australia http://dx.doi.org/10.1093/bioinformatics/bts460

Petit RJ, CsaikI MU, Bordac S, Burg K, Coart E, Cottrell J (2002a) Chloroplast DNA variation in Europe white oaks, Phylogeography and patterns of diversity based on data from over 2600 populations. Forest Ecol Manag 156:5-26

Petit RJ, Brewer S, Bordács S, Burg K, Cheddadi R, Coart E (2002b) Identification of refugia and post glacial colonization routes of European white oaks based on chloroplast DNA and fossil pollen evidence. Forest Ecol Manag 156:49-74 http://dx.doi.org/10.1016/s0378-1127(01)00634-x

Petit RJ, Aguinagalde I, de Beaulieu J-L, Bittkau C, Brewer S, Cheddadi R (2003) Glacial refugia: hotspots but not melting pots of genetic diversity. Science 300:1563-1565 http://dx.doi.org/10.1126/science.1083264

Pospiskova M, Bartakova I (2004) Genetic diversity of a black poplar in the Morava river basin assessed by microsatellite analysis. Forest Genet 11 (3-4):257-262

Pospiskova M, Salkova I (2006) Population structure and parentage analysis of black poplar along the Morava River. Can J Forest Res 36:1067-1076 http://dx.doi.org/10.1139/x06-003

Radosavljević N. 2009: The general management plan of forest and green lands in Autonomous Province of Vojvodina (APV), official document of Provenance government.

Rathmacher G, Niggemann M, Kohnen M, Ziegenhagen B, Bialozyt R (2009) Short-distance gene flow in Populus nigra L. accounts for small-scale spatial genetic structures: implications for insitu conservation measures. Conserv Genet 11:1327-1338 http://dx.doi.org/10.1007/s10592-009-9961-6

Schroeder $\mathrm{H}$, Fladung M (2010) SSR and SNP markers for identification of clones, hybrids and species within the genus Populus. Silvae Genet 59:257-263

Schueler S, Schlünzen KH, Scholz F (2005) Viability of oak pollen and it's implication for long distance gene flow. Trees 19:154-161 http://dx.doi.org/10.1007/s00468-004-0376-1

Smulders MJM, Cottrell JE, Lefèvre F, van der Schoot J, Arens P, Vosman B (2008) Structure of the genetic diversity in black poplar (Populus nigra L.) populations across European river systems: Consequences for conservation and restoration. Forest Ecol Manag 255:1388-1399 http://dx.doi.org/10.1016/j.foreco.2007.10.063

Smulders MJM, van der Schoot J, Arens P, Vosman B (2001) Trinucleotide repeat microsatellite markers for black poplar (Populus nigra L.). Mol Ecol Notes 1:188-190 http://dx.doi.org/10.1046/j.1471-8278.2001.00071.x

Storme V, Vanden Broeck A, Ivens B (2004) Ex-situ conservation of black poplar in Europe: genetic diversity in nine gene bank collections and their value for nature development. Theor Appl Genet 108:969-981 http://dx.doi.org/10.1007/s00122-003-1523-6

Storme V, Vanden Broeck A, Ivens B, Smulders MJM, Halfmaerten D, van Slycken J, Boerjan W (2002) Ex-situ conservation of Black Poplar in Belgium, the margin of the geographical distribution. In: Van Dam BC and Bordács S (eds) Genetic diversity in river population of European black poplar implications for riparian eco-system management; proceedings of the International Symposium, Szekszard, Hungary:61-72

van Dam BC (2002a) Genetic diversity in river populations of European Black poplar populations for evaluation of biodiversity, conservation strategies, nature development and genetic improvement. In: Van Dam BC and Bordács S (eds) Genetic diversity in river population of European black poplar implications for riparian eco-system management; proceedings of the International Symposium, Szekszard, Hungary:15-32

van Dam BC, Vorman B, Pohl A, Smulders MJM, Bovenschen J, Hattemer HH (2002b) Conserving genetic variation of Black poplar along the river Rhine. In: Van Dam BC and Bordács S (eds) Genetic diversity in river population of European black poplar implications for riparian eco-system management; proceedings of the International Symposium, Szekszard, Hungary:117-124 van der Schoot J, Pospiskova M, Vosman B, Smulders MJM (2000) Development and characterization of microsatellite markers in black poplar (Populus nigra L.). Theor Appl Genet 101:317-322 http://dx.doi.org/10.1007/s001220051485

Vanden Broeck A, Storme V, Cottrell JE, Boerjan W, VanBock-Staele E, Quataert P, Van Slycken J (2004) Gene flow between cultivated poplars and native black poplar (Populus nigra L.) a case study along the river Meuse on the Dutch-Belgian border. Forest Ecol Manag 197:307-310 http://dx.doi.org/10.1016/j.foreco.2004.05.021

Van Splunder I, Coops H, Voesenek LACJ, Blom CWPM (1995) Establishment of alluvial forest species in floodplains: the role of dispersal timing, germination characteristics and water level fluctuations. Acta Bot Neerl 44 (3):269-278 http://dx.doi.org/10.1111/j.1438-8677.1995.tb00785.x

Wang J, Li Z, Guo Q, Ren G, Wu Y (2011) Genetic variation within and between populations of a desert poplar (Populus euphratica) reveled by SSR markers. Ann For Sci 68:1143-1149 http://dx.doi.org/10.1007/s13595-011-0119-6

Wehenkel C, Mariscal-Lucero SR, Jaramillo-Correa JP, López-Sánchez CA, Vargas-Hernández JJ, Sáenz-Romero C (2016) Genetic diversity and conservation of Mexican forest trees. In Biodiversity and Conservation of Woody Plants (39 pages). Springer International Publishing, in press.

Wei Z, Du Q, Zhang J, Li B, Zhang D (2013) Genetic diversity and population structure in Chinese Indigenous Poplar (Populus simonii) population using microsatellite markers. Plant Mol Biol 31:620-632 http://dx.doi.org/10.1007/s11105-012-0527-2

Weir BS, Cockerham CC (1984) Estimating F-statistics for the analysis of population structure. Evolution 38:1358-1370 http://dx.doi.org/10.2307/2408641 